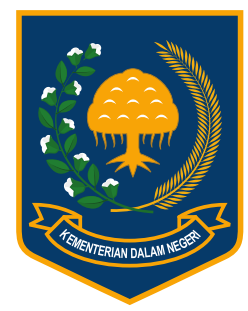

Jurnal Bina Praja 8 (1) (2016): 97-108

Jurnal Bina Praja

e-ISSN: 2503-3360 | p-ISSN: 2085-4323

Accreditation Number

735/AU2/P2MI-LIPI/04/2016

http://jurnal.kemendagri.go.id/index.php/jbp/index

\title{
The DEVELOPMENT OF E-GOVERNMENT SYSTEM IN INDONESIA
}

\author{
Mi'rojul Huda $^{1, *}$, Novy Setia Yunas ${ }^{2}$ \\ ${ }^{1}$ Political Studies Program of FISIP Universitas Brawijaya Malang \\ Jl. Kembang Kertas No. 13A Malang \\ ${ }^{2}$ FISIP Universitas Darul Ulum Jombang \\ Jl. Tembelang No. 331, Tembelang Jombang.
}

Received: 2 February 2016; Accepted: 23 April 2016; Published online: 31 May 2016

\begin{abstract}
The purpose of this study is to provide an overview of the system of electronic-based government or e-government in Indonesia. The development of e-government system in Indonesia is very important to answer the demands of globalization and modernization that are growing rapidly. E-government system is intended so that the governance is easier, faster, transparent, and effective. However, in its development, the implementation of e-government in Indonesia still needs various improvements. Information in this study is obtained from a variety of publications and documents related to the purposes of the study. The results of the study, among others, show that for technology resources, should the current government to allocate funds sufficient to meet the various devices related to the development of e-government. As for human resources, starting now, the government should have a commitment to provide informal education in the field of ICT in the state apparatus and society. To synchronize both strategies, it is necessary to build digital communities (digital society) throughout the region in Indonesia. The existence of digital society is considered not only able to develop better e-government system but also has an impact on economic acceleration. Other than those two things, the most important thing also requires commitment and strong leadership in developing e-government.
\end{abstract}

Keywords: information technology, e-government, public service, effective government.

\section{INTRODUCTION}

Globalization provides its own changes to the order of life in various countries around the world. With globalization, the countries in the world live as though without boundaries or absolute barriers. Many see this as a negative impact of globalization which in turn can erode social values and native culture that developed in each country. But on the other hand, globalization has a positive excess of its own, such as information and communication flows very rapidly to people's lives. The existence of globalization also has close links with modernization. Through the globalization era, the public is like required to conform to all modern life. The implication of the existence and development of globalization and modernization is the rapid development of technology, information, and communication. Such development can be likened to the two sides of different currencies. You could say positive because through the development of technology, information, and communication, the public life is growing with ease. Setiyadi Roes (2003) stated that the existence of technology is believed to be a changer tool. History shows that the evolution of technology has always occurred as a top destination due to concerted efforts of the genius who in turn applied the findings of these technologies to gain ease in life activities and further benefits from it (Setiadi, 2001: 2). But, on the other hand, the development of technology, information, and communication also cause negative effects in which the very rapid development is able to poison the mindset of society towards a less positive direction.

Not only the people, the government, as the authority in the life of the nation and the country, seemingly also required to adjust to this modern life. Modernity here is to adopt the patterns of modern life that are based on technology and information. Demands for applying information and communication technology in order to

\footnotetext{
* Corresponding Author

Phone : +628573119911

Email : mirojulhuda@gmail.com
} 
modernize the government are cited as a form of governance mechanisms and public services based on the technology of electronic government (e-government). The existence of e-government, as well as one of the demands of modernization in the mechanisms of governance and public services, also becomes one of the new pattern in the bureaucratic reform process which requires the implementation of public service to the community which is qualified, professional, transparent, and accountable. Thus, the implementation of e-government becomes an integral part of the efforts to reform the bureaucracy and creating good governance. As a result, the central government and local governments are competing to build an e-government application.

Surveys in several countries indicate that there is a tendency of government officials to not doing their activities online because they prefer the traditional method of service in the form of the direct face, correspondence, or phone. We must learn from the causes of the failure of e-government in some countries due to several factors, namely: the unpreparedness of human resources, information technology infrastructure, and lack of attention from the parties directly involved (Bastian, 2003). All government organizations in the future will inevitably be affected by the development of e-government.

In theory, e-government can be classified into four levels. The first level is to publish government information through the website. Apparently, the presence of official government website is a must, especially in efforts to implement e-government (Baum, 2000:35). Looking at the function, the website is managed with the aim of providing information to the widest public related to government activities and policies that have been issued by the government. The existence of the website as one of the implementations of e-government is part of the efforts to build good governance through one of the pillars of transparency. The second level of implementation of e-government is the interaction between society and government offices through e-mail. The expectation on the existence of the government e-mail is so that via e-mail, people can express criticism, suggestions and aspirations to the government for immediate action in the form of real action (Baum, 2000). However, in terms of implementation, the existence of government e-mail tend to be less optimal because the number of internet users is still very low, especially with the condition of society's resources in which many are still new to the internet. The third level is the community of users can conduct transactions with government agencies on a reciprocal basis (Baum, 2000: 36-37). For this third level, the e-procurement or Electronic Procurement Service (LPSE) can be the example. The main function of this LPSE among others is to organize the procurement of government goods and services on-line. Through the LPSE, the government is increasingly showing that transparency and accountability become an important part in the process of procurement of goods/services to the government. Because indeed, we all know that the procurement of goods/ services has been the most prone to fraud. On the other hand, the example of the fourth level of the implementation of e-government is the existence of a licensing system on-line. The existence of a licensing system in on-line form is part of the implementation of e-government in relation to the reform of the bureaucracy. All this time, people seemed to be complicated by licensing requirements in the government. It eventually became a bad precedent for local public services. And the last level is the integration across government offices, where citizens can transact with all government offices that have had a shared user database.

Reflecting on the development of e-government, then required a concept governance that is done collaboratively among government agencies, nongovernment, community, and the private sector. United Nations Development Program (UNDP) explained that the principle of good governance is a synergistic and constructive relation between state, private sector, and society in the principles of participation, rule of law, transparency, responsiveness, build consensus, equality, effective and efficient, responsible, as well as the strategic vision (UNDP, 1997). Good Governance is defined as the practice of application of authority and improved management of the affairs of state administration in political, economic and administrative manner at all levels.

The greater emphasis on the principle of good governance is the value of accountability. Unfortunately, the meaning of accountability on the old principle of government is still defined as "liability on paper". This perspective makes the concept of accountability at all blind to the reality of the duties and authority seriously undertaken in the field. As a result, the practice of manipulation and corruption in government bodies become completely uncaptured by the meaning of accountability like that (Fadhila Son, 2012).

Good Governance tried to provide new insights related to accountability, with the meaning of "access". Where accountability can be applied when the government provides 'access' profusely to outsiders to know what is being done. In fact, in certain sectors, it also includes free access to participating in the planning, implementation, and evaluation. When there is no access, then the government is considered as not accountable (Fadhila Son, 2012: 194). The problem that arises then is how capable the community is to access information that has 
been provided by the government, with limited education and technology stuttering. Or, as the findings by Puguh Prasetya which revealed that the central and local governments are still using their official websites as bulletin boards (Mandatory Journal, 2013). The existence of the access instead gives an opportunity to those who have superior human resources to access it. Meanwhile, the lowclass people have not been able or unable at all to access the information.

The study of e-government could answer at least three things: first, the e-government provides an analysis of government administration in accordance with the ideals of public service legislation and regional autonomy. Second, e-government is a positive answer to globalization. Third, e-government provides for the strengthening of democracy with IT-based, so as to create the principles of good governance, especially in terms of accountability.

Here, accountability is not only meant to give access to the information given by the government but also gives people the knowledge to be able to access that information. Accountability is not just a matter of accountability and access reports. Accountability is about the protection of the public from abuse of power (Fadhila Son, 2012). The global condition is always characterized by complexity and openness, and accountability that makes the producers and providers of service increasingly sensitive to the complexities of reality.

\section{MeThoD}

This is a descriptive study with literature study (library research), which describes the implementation of e-government in Indonesia with its numerous problems. Library research is research that is based on information from scientific publications, previous research, or other written sources of support. The main information sources in this study are obtained from the analysis of previous research publications and other documents related to the study objectives. In this study, the process of data analysis used is qualitative data analysis. Analysis and interpretation of this are done with reference to the theoretical foundation of researchrelated problems.

\section{RESULT AND DISCUSSION}

\section{A. Implementation of Electronic Government (e-Government) in Indonesia}

Talking about one form of the development of technology, information, and communication as the implications of globalization and modernization that are very rapid, it seems people can not escape from these developments. Not only the people, the government as the authority in the administration of political life, nation, and state is also required to participate in adopting technology and communication development in governance and public services. At present, the development of Internet technology as a form of development and information technology has reached a stage of rapid growth.

A study conducted by the Organisation For Economic Co-Operation and Development (OECD), said that the use of Information Technology in governance can enhance citizen participation in policy making. A government can adopt the use of information technology as a form of democratic government. The advantages to be gained from the use of information technology as defined by the Macintosh (2003) are as follows: (1) information technology is able to reach the broader community to increase participation in policy formulation as deepening democracy. (2) Supporting the participation through the presence of technology and to provide access and teach people to take advantage of the access provided as a public communication path. (3) Providing information that is easily accessible and easily understood as a form of accountability to the public. (4) Bringing together a wider informant in order to form a more deliberative public space.

The use of information technology such as Internet application is already in use on the environment of government, known as e-government. The central government and local governments are competing to make e-government applications. The development of e-government applications requires substantial funding so that the readiness of the human resources of government officials and the readiness of society is needed. Surveys in several countries indicate that there is a tendency that government officials should do their activities online because they prefer the traditional method of service in the form of the direct face, correspondence, or phone. We must learn from the causes of the failure of e-government in some countries due to several factors, namely: the unpreparedness of human resources, information technology infrastructure, and lack of attention from the parties directly involved (Bastian, 2003).

E-government is the use of information technology and telecommunications for efficient and effective administration and provides transparent and satisfactory service to the community. All government organizations will be affected by the development of e-government.

\section{B. Existing Condition of E-government Development in Indonesia}

The development of e-government as the 


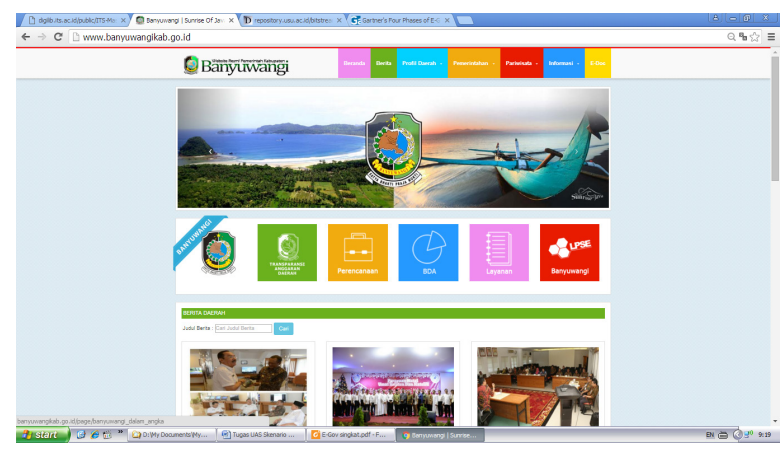

Figure 1. The Government Website Overview Source: Website of Banyuwangi District (www.banyuwangikab. go.id)

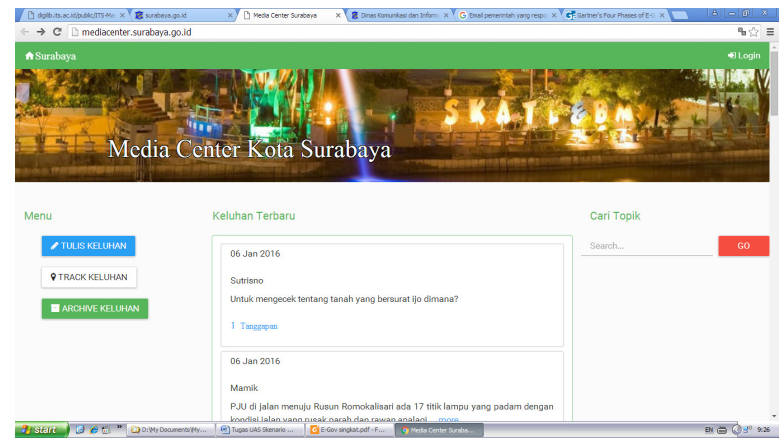

Figure 2. Overview of Community Media Center Portal Source: Website of Media Center of Surabaya City (mediacenter.surabaya.go.id)

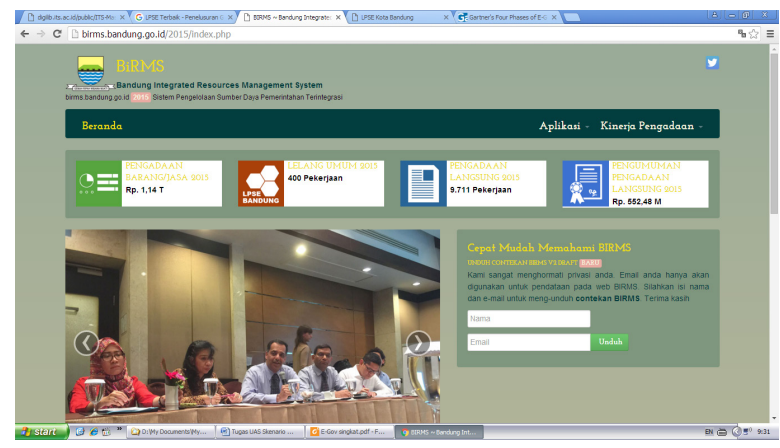

Figure 3. Overview of Integrated Government Website Source: Bandung Integrated Resources Management System (http://birms.bandung.go.id/)

implication of the rapid development of technology and information flows inevitably affects the patterns and mechanisms of IT-based governance in Indonesia. The development of e-government in Indonesia seems to have come to a process where the government has set the legal basis for the development of the program in the framework of the transformation to good governance and the reform of the bureaucracy. The government, through the Presidential Instruction No. 3 of 2003 on national policy and strategy development of e-government, has high hopes for the implementation of policies related to the development of e-government which include: First, a change which requires the establishment of governance that is clean, transparent, and able to answer the changing demands effectively. The government should be able to meet two modalities of the community's different but closely related demands, namely: the people demand public services that meet the public interest throughout the country, reliable, trustworthy, and easy to reach interactively. As well, the public wants their aspirations to be heard, thus, the government must facilitate public participation and dialogue in the formulation of state policy (Presidential Instruction 3/2003 on National Policy and Strategy Development of e-government).

To answer these challenges, central and local governments should seek to form a new dimension to the organization, management systems, and work processes that include the following: (1) So far the government implements the system and work processes which are based on a rigid bureaucracy. Such system and work processes are not possible to answer such a complex and dynamic changes, and the need to respond quickly. Therefore, in the future, the government must develop a more flexible system and work process to facilitate various forms of complex interactions with other state institutions, communities, businesses, and the international community. (2) The management system of the government thus far is a hierarchical system of authority and sectoral command that is conical and long. To satisfy the needs of an increasingly diverse community in the future should be developed a modern management system with the networked organization so as to shorten the lines of decisionmaking and broaden the span of control. (3) The government should also loosen the separation wall that limits interaction with the private sector, government organizations must be more open to forming partnerships with the business world (public-private partnership). (4) The government should be able to take advantage of advances in information technology to improve the ability to process, manage, distribute, and information distribution and public services.

Thus, the government should immediately implement the transformation process towards e-government. Through the transformation process, the government can optimize the utilization of advances in information technology to eliminate the barriers of bureaucratic organization, and form a network management system and work process that allows government agencies to work in an integrated manner to simplify access to all the information and public services to be provided by the government. Thus, all state institutions, communities, businesses, and other interested parties can at any time take advantage of government information and services optimally. This requires strong leadership at each 
institution or unit of government so that the process of transformation towards e-government can be implemented as well as possible.

Viewing the enormous expectation of the government, then all levels, both national and local government, compete with each other, straighten it up and set up all the resources to create the e-government applications. For example, each region now has at least an official website run by the purpose of providing information to the widest public related to government activities and policies that have been issued by the government. Then, the provision of e-procurement system application or LPSE (electronic procurement services) which is intended to provide services to the procurement of goods and services in an open manner (transparent) so that the public can monitor directly and there will be no deviation as well as foul play. In addition to the official website and LPSE, there is also local government such as Surabaya that makes the system of licensing application on-line, named Surabaya Single Window (SSW), which was launched in 2013. The SSW is a one-stop system that is based online. This system is integrated and connected with several offices in the city of Surabaya so that the licensing service is straightforward and investors from outside the region do not have to come to Surabaya. The existence of SSW will provide service to the community's licensing service which is considered complicated, time-consuming, and cost a lot of money. Through the application system, the government is trying to create a qualified and useroriented public service in order to transform and change the service.

Besides SSW, Surabaya city has also implemented online-based regional development planning system (e-musrenbang), which has been initiated since 2009. E-Musrenbang is present to answer the demands of the public for transparency and openness in terms of development. E-musrenbang is implemented hierarchically from urban-village, sub-district, and city to agree on an online regional development plan for one year. Unfortunately, the presence of SSW and E-Musrenbang in Surabaya have constraints not in the government administration, but from the public (the Goddess, 2014). The people of Surabaya are still not ready to accept the innovation of e-government program of the government.

The examples from another region are in Bojonegoro. Unlike the city of Surabaya, which has become one of the major cities in Indonesia, Bojonegoro is a district that was previously not widely known to Indonesian public except for the matter of oil and gas. In early April 2016, Bojonegoro received an award as the pioneer city of the Open Government Partnership, along with the City of Seoul (South Korea) and Tbilisi (Georgia), which became the first pilot region in Asia, coupled with 13 major cities in the world and 45 cities that register in this event (http://www.koran-jakarta.com/). This award cannot be separated from Bojonegoro government's commitment to improving the quality of public services. Over the last 8 years, Bojonegoro has been trying to raise public trust through transparency of information. Suyoto, as Regent of Bojonegoro, insisted that public disclosure is crucial to maintaining public confidence in the government district, in which the confidence will define public participation in development (OGI, 2016). In addition to performing regular public consultations in the district marquee, Bojonegoro government also uses technology to disseminate information to the public, while absorbing existing aspirations and forward it to the agency concerned. Not only that, Suyoto also received the reports on the progress of aspirations and complaints from citizens each day, how many complaints are received, and how many are responded to and dealt with.

With such quite dynamic development, now the questions arise are: whether the system built is indeed applied on the initiative to make changes in the mechanism of governance and public services? Or only limited to political demands and the development of the era? It can be explained that the first, the existence of e-government is a form of the demands of the times and political demands for the issuance of policy. Thus, inevitably central and local governments and their staffs must prepare all resources to build such system. This can be seen both positively and negatively. Positively, from the demands, all levels of government are trying to make a change towards good governance and qualified public services. At least, they have the initiation of e-government system construction. Whereas, if viewed from the negative side, the development of e-government system is somewhat forced. The imposition of the will is, for example, the existence of the e-mail application of the government currently seems unable to work optimally. People sometimes send an e-mail containing the complaint or information, but no reply or response from the government. It is then breaking the public's expectations related to the presence of e-mail that the government is expected to provide a response to the problems faced by the community. Based on data from the Public Service Commission (KPP) in East Java province alone, within the period of 2007 to 2014, there were four thousand complaints dominated by the big cities. Although KPP claimed to have completed $75 \%$ of complaints received (http://kominfo.jatimprov.go.id), but with a decrease in the number of complaints each year, as well as difficulties of the society to access the website of Easy Java KPP, indicate that the service of complaints has not run optimally, Although it can 
not be denied that today many institutions have opened complaints service.

Then, in terms of the development of the official website, the official website sometimes is less optimized by the administrator. For example, the admin does not perform an update on the news that should be obtained by the public accurately or update data bank intended for the public, such as data related to the medium-term development plan and so forth. It was again the weakness of the system providing the application. Unlike the LPSE system, this system is also considered less than optimal. LPSE is built with an expectation that the system is able to minimize the fraud in the procurement of goods/services by the government, but in the implementation, very few procurements of goods/services through LPSE and irregularities in the procurement process of goods / services are still common.

Judging from the progress of the development of e-government application system above, it can be concluded that the development of e-government in Indonesia is still in the process that needs to keep improving. That is, the development of e-government can be a success or failure in the future.

\section{Constraints and Supports on Future Development of E-Government in Indonesia}

As a developing country, the application of e-government in Indonesia is not classified as encouraging even though the government has tried to formulate a lot of legislation related to information technology. If compared to neighboring countries

Table 1.

Rank of e-Government Readiness in Southeast Asia in 2005-2008

\begin{tabular}{clccc} 
Rank & \multicolumn{1}{c}{ Country } & $\mathbf{2 0 0 4}$ & $\mathbf{2 0 0 5}$ & $\mathbf{2 0 0 8}$ \\
1 & Singapore & 8 & 7 & 23 \\
\hline 2 & Malaysia & 42 & 43 & 34 \\
\hline 3 & Thailand & 50 & 46 & 64 \\
\hline 4 & The Philippines & 47 & 41 & 66 \\
\hline 5 & $\begin{array}{l}\text { Brunei Darus- } \\
\text { salam }\end{array}$ & 63 & 73 & 87 \\
\hline 6 & Vietnam & 112 & 105 & 91 \\
\hline 7 & Indonesia & 85 & 96 & 106 \\
\hline 8 & Cambodia & 129 & 128 & 139 \\
\hline 9 & Myanmar & 123 & 129 & 144 \\
\hline 10 & Timor Leste & 174 & 144 & 155 \\
\hline 11 & Laos & 144 & 147 & 156 \\
\hline
\end{tabular}

Source: Global e-Government Readiness such as Singapore and Malaysia, it is really obvious that the application of e-government Indonesia is still lagging. Based on survey results described by the Global E-Government Readiness in 2005-2008, Indonesia's rank in the category Southeast Asian countries in the implementation of e-government comes out as follows:

The low quality of e-government in Indonesia can not be separated from the unequal distribution of human resources in Indonesia, affecting the implementation of e-government in some regions. On the one hand, some regions are capable of implementing e-government system well, even to the village level. But on the other hand, the implementation of e-government is not running at all, even at the level of district or city. A recent study released by the UN in 2014 on E-Government Survey, Indonesia is in a position of 106 out of 193 countries in the world. This indicates that there has been no significant change from the ranks of e-government in Indonesia in recent years.

Studies conducted by Heeks in 2003 about the use of e-government indicate that $35 \%$ of e-government programs around the world have failed, $50 \%$ are failed in part and only $15 \%$ are considered successful (Heeks, 2003). There are many factors that influence the failure of the implementation of e-government, and certainly the most decisive are the lack of a commitment to reduce the digital gap between us and developed countries in addition to the factors of infrastructure and difficult geographical conditions. In the development of e-government in Indonesia, it is not free from the constraints and supports that emerge, among others: (1) factors that hamper is the unavailability of human resources (HR) that is inadequate or minimal in terms of managerial skills and management. The government generally rarely have competent human resources in the field of e-government. HR that is reliable and willing to learn new fields, usually located in business and industrial environment. The problem of the availability of human resources with ICT field competency standards is more difficult than for the technology issues. This not yet equal public's understanding is related to the use of e-government for the majority of the population that are in the line of the lower middle class. It is the factor that causes doubt in implementing e-government (Simangungsong, 2010). (2) Factors that become an obstacle in the implementation of e-government in Indonesia is the market penetration of hardware and service providers of information and communication technology services have not been evenly distributed to the regions, thus occurred problems in its infrastructure, which is also still inadequate. Relatively high cost has also become one of the factors inhibiting the development of infrastructure. 
Until recently, many government offices have built LAN network in each unit of work, but the LAN network is not connected to LAN network with other working units (Simangungsong, 2010). (3) In the development of e-government, government as one of the stakeholders should know what problems there are, what is needed, and how to overcome the existing problems. Some e-government applications can notanswer the problems thatarise. As an example of the case is the application of e-Procurement (LPSE), during job description, there should be a real-time interaction between bidders and procurement committee (Simangungsong, 2010). (4) Organizational communication, communication flow in the management of e-government still hit by bureaucracy line becomes one of the inhibiting factors in the development of e-government. The commitment of top management is one of the much-needed supports. Until now, the government projects in the field of e-government are mostly ceremonial. Built with high cost, well-intentioned, but not well utilized (Simangungsong, 2010: 15).

In addition to the barriers which have emerged in the development of e-government in Indonesia, there are several forms of the success factors (support) in the future development of e-government in Indonesia, among others: (1) Vision, Objectives, and Strategy. It takes a clear vision of leadership, strong support from the community, and the establishment of a clear agenda. (2) Clear Regulation and Law. So far, the policies and laws are like two sides in the development of e-government throughout the world, including in Indonesia. On the one hand, inappropriate policy and law make the implementation of e-government becomes constrained, contrary to the right policy and law, the e-government implementation will be in line with expectations. One of the roles and functions of law in the development of e-government is the law of privacy and related issues. In addition, it takes the laws governing changes in business processes and information systems. The most important thing of the regulations and laws is that laws are related to government information technology architecture and the establishment of an integrated computer data center (Lee 2010: 28). (3) Organizational Structure. Organization becomes one of the important indicators in the successful implementation of e-government in the future. There are several important things that affect organizational change in the development of e-government in the future; First, Strong leadership with commitment. Learning from the experiences of international countries shows that the success of the transformation and change in the governance of the organization, especially on the bureaucracy in the country, highly dependent on the commitment and character of leadership. the elaboration of such purposes is: first, the most important are their commitment to modernization, transformation, and changes to the values and structure of the mechanism of action of the organization. That is, conducted a fundamental change in the creation of an organizational culture that more emphasis on new/modern values and culture mainly on the value of focusing on service to the public. Second, the needed commitment to a successful process of transformation or change of an organization is the commitment to the enforcement of the law (supreme of law). Law enforcement has become a central issue at this time. Law enforcement is required in various deviant acts against organizations such as the implementation of maladministration, corruption, collusion, nepotism and other indiscipline actions. Both commitments seem to be the basic commitments to the implementation of changes to governance and organizational structure in this country in the framework of the successful implementation of e-government in the future. However, these commitments will not make it without what is called leadership character. Leadership character is importantly needed to create and run a wide range of policies. Leadership Character required, in this case, is a model of decisive leadership, responsive to the aspirations of the community, consistent, and that is not constrained by other interests. Without the existence of strong and good commitment and leadership character then hopes or ideals to create a system of governance based on technology, information, and communication will be wasted or only to the extent of blueprint in a vacuum space. In addition to strong commitment and leadership, to implement e-government in Indonesia, needed IT management planning and change management, budget preparation and budget execution, coordination and collaboration, monitoring and performance measurement, and the most important thing is the attempt to build a partnership between government, the private sector, and communities (Lee, 2010). (4) Business Process. The successful implementation of e-government is not only supported by the policy aspects and government support, Business Process Reengineering (BPR) is also important or, in other words, innovation in the business process is oriented to the development of technology and information (Lee, 2010). (5) Wellestablished Information Technology. In addition to human resources that support the development of e-government in Indonesia, one of the important things is the information technology resources. There are some things that are important from the information technology resources in the future development of e-government in Indonesia, among others: the level of needed application technology, network infrastructure, applications that synergize with each other (interoperability), standardization, 


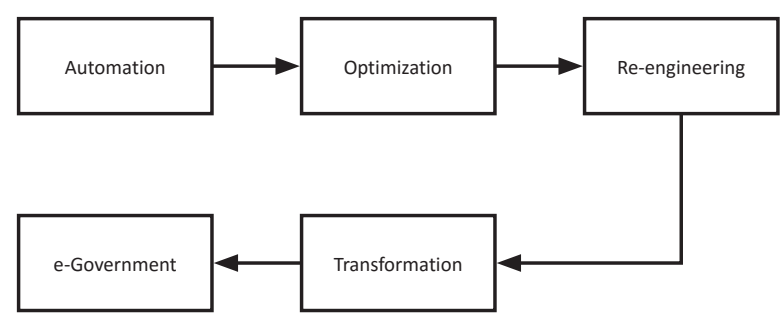

Figure 4. Flow of e-Government Long-term Strategic Planning Phase in Indonesia

Source: Journal of Ministry of Finance, Republic of Indonesia

and technical and Human Resources ability (Lee, 2010)

\section{100-year Development Strategy of E-government in Indonesia}

A strategic plan provides a roadmap for the organization to move from the current state to the desired conditions in the long term. There are four phases of strategic planning in the long-term development of e-government in Indonesia:

First Phase: Automation. In this phase, a shift from manual era to the era of the automated or digital era. All matters related to public services, which can be made based on ICT, migrated from manual to electronic. Phase two: Optimization. After the first phase has passed, then the government performs optimization efforts. Facilities and infrastructure are well used in such a way so as to encourage economic growth. Phase three: Re-engineering. The next phase is re-engineering. Gradually, various policies should be adjusted so that e-government policies can be implemented properly. And the final phase: transformation. The final stage is transformation. The pattern of business process services and government offices changed to make ICT as a base that facilitates all affairs. The main principles are if it can be simplified, why should be complicated (Tohirin, 2015).

Once this phase is reached, then the next strategy is the development plan of ICT-based public services that refer to the integrated Governmentto-Government (G2G), Government-to-Business (G2B) and Government-to-Citizen (G2C). The main objective of the development of service-based Government to Government (G2G) is innovating the way government works. There are several types of services that can be developed refer to this type of G2G, such as (1) Integrated Financial Information System. In the government financial management sector, it is important to link all financial information systems operating independently in various government agencies. Financial Information Systems Integrated is designed including various features such as Module Budget Preparation and Budget Allocation, covering the entire government budget process, Management Module Receipts and Payments which includes the collection of income taxes and non-tax and public expense, General Ledger Module covers the recording of all financial transactions, year-end closing and fiscal reporting of each government entity, Module Cash management includes financial forecasts, allocating finance, and financial operations by the central bank, Asset Management and Loans Management Modules that include the management of national property, such as land, buildings, aircraft and ships, as well as the state management risk towards these assets, Consolidated Finance Statistics Module includes the processing of fiscal reports based on consolidated financial information of all government agencies, Financial Analysis Module includes macroeconomic forecasts and simulations, analysis of financial index, and performance measurement. The expected results of the Financial Information Systems Integrated are among others: the network of financial information eliminates the boundaries of space and time, enabling financial transactions 24 hours a day, 7 days a week and 365 days a year so that it creates momentum for local financial markets to thrive by creating a sharing financial information platform. The most important thing with the development of this network is that it is expected to help strengthen the international competitiveness of the financial industry. (2) The local e-government system. E-government system in the regions is expected to cover the whole concept of e-government area and two levels below the e-government such as municipal/provincial administration Information and the administration improvement of city/regency/ district. Besides, the existence of local government based on digital allows real-time information exchange through vertical and horizontal relationships between central and local administrative agencies. Through the development of it, has improved efficiency and customer service has been improved with the electronic processing infrastructure for administration and community petition. The results of the development of this local e-government system are the exchange basic information needed is expected to occur for community affairs, such as housing, land, and vehicles. The number of documents required to be prepared by applicants has decreased and a visit to the institution is no longer necessary. In addition, when the health and welfare services change the paradigm, which was first business-oriented, to customer-oriented, it is assumed the number of forms needed will be reduced to 13 compared with the previous number of 60 (Lee, 2010).

Meanwhile, the main purpose of the development of service based on Governmentto-Business (G2B) is the innovation on business services. There are several types of services that can be developed referring to this type of 


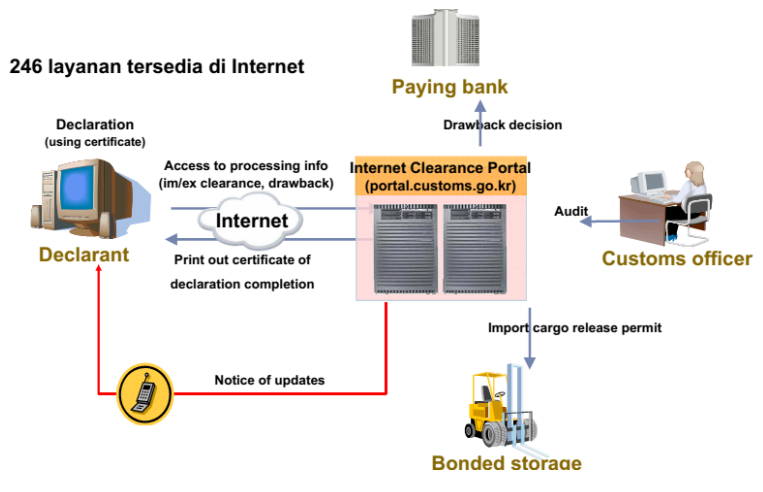

Figure 5. Flow of Online Custom System Development Source: UN-APCICT

G2B, such as (1) Integrated Procurement System (e-Procurement). E-Procurement is an online system that allows convenient and rapid processing for all administrative procedures related to public procurement, including the submission of price, contract, payment, and delivery of products. The procurement process which previously relied on letters and personal visits are now computerized. This creates a paperless government procurement system as the best e-marketplaces for the private sector. Procurement information includes the purchase request, the auction announcement, the winning of contracts, and contract status are provided real-time on the Internet. (Lee, 2010).

(2) Customs Application System. The purpose of the development of e-customs system is, first, to establish an information system that supports the customs administration; second, to stop the smuggling; Third, to reduce logistics costs in the import and export industry; and fourth, to improve the quality of customs services offered. The results of the development of e-customs are customs clearance procedures such as a report on export / import, permits to dry dock, and freight data management which is all computerized. Customers can skip their goods from the office by simply using the mouse. Requires only 8 days from the port of entry to the delivery of goods than before, which was 23 days. And export licensing only takes 2 minutes compared with the earlier which reached 4 hours. Through the e-custom systems, completion of export affairs can now be processed in two minutes and the completion of the import business in just 1.5 hours (Lee, 2010). (3) E-Commerce. E-commerce refers to the buying, selling, marketing, and service of products and services via the Internet or other computer networks. E-Commerce handles the purchase and transfer of funds through a computer network. The role of government in e-commerce is to allow the business community to get valuable information and apply them at the right time on the production and sale of goods and services.
e-Commerce is built on the structure and profits of traditional trade by adding flexibility offered by electronic networks. One key feature of e-commerce transaction is the provision of business-to-business (B2B) to promote small and medium enterprises (SMEs) (Lee, 2010).

The existence of a system that is based on a Government-to-Citizen (G2C) is that inefficiencies in public administration can be found by the existence of separated national databases, such as databases of population, land, motor vehicles and taxation. During this time, the existence of a separate database means that people have to double register, through a long process of working papers for various licenses, and requires multiple visits to government institutions. There are several types of services that can be developed referring to this type of G2B, such as (1) Public Services Online. The so-called online community services include: One-Stop Citizen Service Centres, where the single-window service presented by way of cooperation between the institutions to serve people who prefer or are only able to do face-to-face interaction; Telecenters: Public access points with free or subsidized access to e-government services (via postal network, libraries, schools, community centers and others; Call Centers: The delivery of services through telephone call centers provided by the government; Web Portals: Submission Service through government web portal that is easy to use and interoperable technology-based; M-government: the delivery of mobile services via SMS messaging and m-government portal that is specifically designed; T-government: the delivery of service that is interactive digital TV-based through the government channel/portal designed specifically, with the content that is broadcasted and on-demand (Lee, 2010). The outcomes of this system are that people can make an application to access and obtain certification documents through a variety of online public administration services anytime and anywhere. In addition, the community service system can improve the quality of life and administrative convenience by providing services with documents and fewer visits. (2) Integrated Taxation System. The integrated online tax system is built to facilitate the use of Home Tax Service (HTS), which is more convenient for the tax affairs such as notices, references, and related tax payments. There are several objectives of integrated development of the tax system, among others: increased tax revenue, prevent corruption, increase awareness of paying taxes, build better tax administration, and ensure public service is fast and accurate. Online tax system covers income tax, corporation tax, value added tax (VAT), property tax (PBB), and various other taxes. An important result to be achieved from the development of this online-based taxation system, 


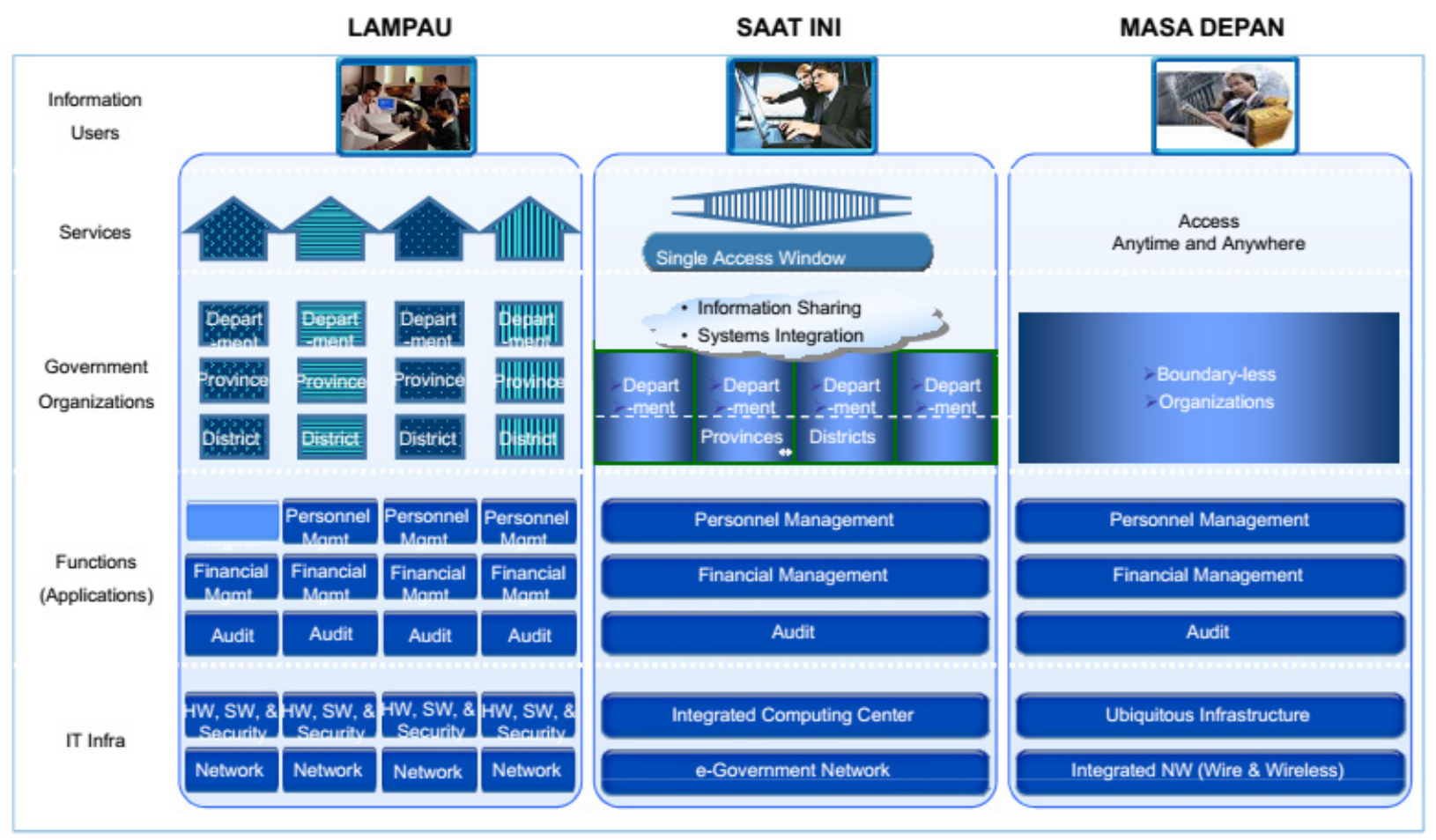

Figure 6. Roadmap to e-Government Development Source: UN-APCICT

among others, is by minimizing waste and speeding up data entry tax affairs, the integrated tax system improves operating efficiency and reduces costs. On the other hand, the development of online-based taxation system is able to increase the transparency in the process of taxation and taxpayers can save on travel costs and personal visit to the tax office. (3) Integrated Insurance System. The existence of an integrated insurance information system resource includes information on four major insurance markets, namely the national pension, health insurance, accident insurance, and employment insurance. The purpose of the integrated insurance system is to improve the quality of service and facilitate the exchange of information between government agencies. The completion of the interconnection of information systems allows one-stop service for participation, changes, and the withdrawal from service of insurance towards four types of insurance services. (4) Population census application.

Management of population census originally used a manual recording of population information on the book along with information such as registration, changes, and expiration time. This process is inefficient and rescuing data can not be done in the case of loss or damage to the ledger. Even, to do a change of address takes three days. In the presence of online-based population census system application, then the processing time for any request is decreased to a few minutes earlier than before that could be for days. This has increased the efficiency and quality of service (Lee, 2010).

From the various long-term strategic plan of e-Government development in Indonesia, the end goal is how to make e-government the modernization of ICT-based governance system which is able to improve service quality and minimize the level of public visits to the office of the service. Society in the future no longer needs to come to the office of the administration to change the address on demographic data, pay taxes, or just to take care of building permits and so on. This is the conveniences offered by the future development of ICT-based governance system. The continuity of public services with the use of IT certainly has some risks and threats, both naturally and because of human error. Therefore, it is necessary to identify the risks and threats to ease the risk management of IT-based services.

\section{ConClusion}

The development of the world is increasingly modern. Globalization requires all countries in this hemisphere to move quickly to follow developments in it. Including modernization issues that are part and parcel of globalization, one of which is political modernization and various instruments in it. To pursue the development of the world, which grew rapidly from day to day, it takes a strategic planning in any development of political modernization products and instruments of government, in this case, the e-government. The objectives of e-government, 
in general, is so that the system of government be more efficient, transparent, and effective. Thus, the process of public services, such as licensing, payments, up to budgeting, does not have to be face to face. The process is faster, transparent, and can be tracked if there is a delay or abuse of authority. The development of e-government in Indonesia is still in need of improvement. International Academy of CIO in collaboration with Waseda University, Japan, measured and then ranked the e-government. The measurement takes place every year since 2005. In 2014 , Indonesia ranked 32 nd out of 62 countries measured. USA, Singapore, Korea, UK and Japan respectively in the top five. Seeing this reality, it would require some development strategies.

First, needed more concrete policies than the blueprint and roadmap which contains only the high expectations alone without any follow-up.

Second, in the aspect of technology resources, starting today the government should allocate sufficient budget in of state financial structure to meet a variety of technological tools and information needed in the development of e-government. The budget is used to establish access to the telecommunications network, the Internet and other communication media that can be used by citizens to access public services site widely. If access to telecommunications networks and Internet networks has been available well _, then needed a synergy between government, communities and the private sector in building digital communities (digital society).

Third, in the aspect of human resources, from this moment the government must be committed to providing guidance and informal education in the field of technology, information, and communication for the state apparatus and society. Human resources for the development of e-government in the future needs to be carefully prepared. The existence of digital communities (digital society) then becomes necessary in order to create a society that is literate to the use of technology, information, and communication, especially for developing e-government in Indonesia for the better. Moreover, digital communities (digital society) is capable of being one of the instruments of economic acceleration in local and national scale.

Besides those two things, most important thing is strong commitment and leadership character are needed in developing e-government. Without the existence of strong and good commitment leadership, then hopes or ideals to create a system of governance that is based on technology, information, and communication will be wasted or only to the extent of blueprint in a vacuum place. Commitment and leadership character become important to do transformation and change in terms of electronicbased government administration, because in reality, the public and government officials tend to be difficult to implement new patterns that are more modern.

\section{REFERENCES}

Azizy, A. (2007). Change Management dalam Reformasi Birokrasi. Jakarta: Gramedia Pustaka Utama.

Bastian,. (2003). Perkembangan e-Government di Indonesia. Bappenas.go.id. Retrieved 8 January 2013, from http://www.bappenas.go.id/index. php? module $=$ ContentExpress $\&$ func $=$ display $\&-$ ceid=1693

Baum, C. \& Maio, A. (2000). Gartner's Four Phases of e-Government Model. California: Gartner Publishing.

Bojonegoro Pelopor "Open Government" di Indonesia. (2016). Koran-jakarta.com. Retrieved 23 April 2016, from http://www.koran-jakarta.com/ bojonegoro-pelopor-open-government-di-indonesia/

Cetak Biru (Blueprint) Sistem Aplikasi e-Government bagi Lembaga Pemerintah Daerah. Jakarta. Retrieved from http://perpustakaan.bappenas. go.id/lontar/file?file=digital /125450-\%5B_ Konten_\%5D-Konten\%20C8661.pdf

Deputy Secretary Cabinet,. (2003). Indonesian Presidential Instruction No 3 of 2003 on National Policy and Strategy Development of e-Government. Jakarta: Deputy Secretary Cabinet.

Dewi, L. \& Mudjahidin,. (2014). Analisis Penerapan Aplikasi Surabaya Single Windows Pemerintah Kota Surabaya Menggunakan Government Adoption Model (GAM). Jurnal Teknik POMITS, 3(2), A210-A215.

Governance for Suitable Development - A Policy Document. (1997). New York.

Lee, N. (2009). Penerapan e-Government. Yeonsu: United Nations Asian and Pacific Training Centre for Information and Communication Technology for Development.

Macintosh, A. (2004). Using Information and Communication Technologies to Enhance Citizen Engagement in the Policy Process. In Promise and Problems of E-Democracy: Challenges of Online Citizen Engagement (pp. 19-142). Paris: OECD.

Maliki, I. (2010). Manajemen Resiko Teknologi Informasi I Untuk Keberlangsungan Layanan Publik Menggunakan Framework Information Technology Infrastructure Library (ITIL Versi 3). In Seminar Nasional Aplikasi Teknologi Informasi (SNATI 2010).

Putra, F. (2012). New Public Governance. Malang: UB Press.

Refleksi Lima Tahun KPP Jatim, dari 4 Ribu Pengaduan, sekitar 75\% Terselesaikan. Kominfo.jatimprov.go.id. Retrieved 26 August 2015, from 
http://kominfo.jatimprov.go.id/watch/28400

Setiyadi, M. (2001). E-Government: Strategi Meraba Gajah. Retrieved from http://www.insteps. or.id/File/.../E-govt-strategi\%20meraba\%20 gajah.pdf

Simangunsong, J. (2010). Pengembangan E- Government di Indonesia. Jakarta: Universitas Indonesia.

Sudarto, Y. (2006). e-Government dan Reformasi Birokrasi Menuju Pemerintahan yang Baik. Bandung: KNTIK.

Tohirin,. (2014). Korea's Experiences Learning Good
Governance and e-Government. Bppk.kemenkeu.go.id. Retrieved 10 January 2016, from http://www.bppk.kemenkeu.go.id/publikasi/ artikel/147-artikel-anggaran-dan\%20perbendaharaan/20252-korea\%E2\%80\%99s-exp e r i e n c e s- le a rn ing-good - governance-and-e-government

United Nations e-Government Survey 2014. (2014). New York.

Utomo, P. (2013). Website Sebagai Media Pemenuhan Hak Politik Warga dalam Penyelenggaraan Pemerintahan. Jurnal Mandatory, 10(2), 59-88. 